\title{
Beneficial effects of leptin on obesity, $T$ cell hyporesponsiveness, and neuroendocrine/metabolic dysfunction of human congenital leptin deficiency
}

\author{
I. Sadaf Farooqi, ${ }^{1}$ Giuseppe Matarese, ${ }^{2}$ Graham M. Lord, ${ }^{3}$ Julia M. Keogh, ${ }^{1}$ \\ Elizabeth Lawrence, ${ }^{4}$ Chizo Agwu, ${ }^{5}$ Veronica Sanna, ${ }^{2}$ Susan A. Jebb, ${ }^{6}$ Francesco Perna, ${ }^{7}$ \\ Silvia Fontana, ${ }^{2}$ Robert I. Lechler, ${ }^{3}$ Alex M. DePaoli, ${ }^{4}$ and Stephen O'Rahilly ${ }^{1}$
}

\author{
${ }^{1}$ University Department of Medicine and Department of Clinical Biochemistry, Addenbrooke's Hospital, Cambridge, \\ United Kingdom \\ ${ }^{2}$ Centro di Endocrinologia ed Oncologia Sperimentale, Consiglio Nazionale delle Ricerche (CNR-CEOS), Naples, Italy \\ ${ }^{3}$ Department of Immunology, Imperial College School of Medicine, Hammersmith Hospital, London, United Kingdom \\ ${ }^{4}$ AMGEN Inc., Thousand Oaks, California, USA \\ ${ }^{5}$ Department of Paediatrics, Sandwell Hospital, West Midlands, United Kingdom \\ ${ }^{6}$ Medical Research Council, Human Nutrition Research, Cambridge, United Kingdom \\ ${ }^{7}$ Cattedra di Malattie dell'Apparato Respiratorio, Dipartimento di Medicina Clinica e Sperimantale, Universita di Napoli \\ Frederico II, Naples, Italy
}

The wide range of phenotypic abnormalities seen in the leptin-deficient $o b / o b$ mouse and their reversibility by leptin administration provide compelling evidence for the existence of multiple physiological functions of this hormone in rodents. In contrast, information regarding the roles of this hormone in humans is limited. Three morbidly obese children, who were congenitally deficient in leptin, were treated with daily subcutaneous injections of recombinant human leptin for up to 4 years with sustained, beneficial effects on appetite, fat mass, hyperinsulinemia, and hyperlipidemia. Leptin therapy resulted in a rapid and sustained increase in plasma thyroid hormone levels and, through its age-dependent effects on gonadotropin secretion, facilitated appropriately timed pubertal development. Leptin deficiency was associated with reduced numbers of circulating $\mathrm{CD}^{+} \mathrm{T}$ cells and impaired $T$ cell proliferation and cytokine release, all of which were reversed by recombinant human leptin administration. The subcutaneous administration of recombinant human leptin has major and sustained beneficial effects on the multiple phenotypic abnormalities associated with congenital human leptin deficiency.

This article was published online in advance of the print edition. The date of publication is available

from the JCI website, http://www.jci.org. J. Clin. Invest. 110:1093-1103 (2002). doi:10.1172/JCI200215693.

\section{Introduction}

Lacking the adipocyte hormone leptin, ob/ob mice develop severe obesity as a result of a combination of increased food intake and diminished energy expenditure (1). In addition to obesity, the congenital deficiency

Received for publication April 15, 2002, and accepted in revised form August 13, 2002.

Address correspondence to: I. Sadaf Farooqi, University Department of Medicine and Department of Clinical Biochemistry, Addenbrooke's Hospital, Cambridge, United Kingdom. Phone: 441223 762634; Fax: 441223 762657; E-mail: ifarooqi@hgmp.mrc.ac.uk.

Giuseppe Matarese and Graham Lord contributed equally to this work.

Conflict of interest declared: Elizabeth Lawrence and Alex M. DePaoli are employees of AMGEN Inc.

Nonstandard abbreviations used: recombinant human leptin (r-metHuLeptin); lean body weight (LBW); dual-energy x-ray absorptiometry (DXA); basal metabolic rate (BMR); folliclestimulating hormone (FSH); luteinizing hormone (LH); murine IL-3 (mIL-3); phytohemagglutinin (PHA); total energy expenditure (TEE); SD score (SDS); bone mineral content (BMC); bone mineral density (BMD); free tri-iodothyronine (fT3); free thyroxine (fT4); thyrotropin (TSH); tuberculin purified protein derivitive (PPD). of leptin in mice results in a wide range of other phenotypic abnormalities. The $o b / o b$ mice are infertile as a result of hypogonadotropic hypogonadism (2). They have high circulating glucocorticoid levels that may contribute, by suppressive effects on growth hormone secretion, to their diminished linear growth (3). Leptin-deficient mice adapt poorly to cold exposure (4) and have impaired regulation of the hypothalamo-pituitary-thyroid axis (5). They develop hyperinsulinemia and often progress to diabetes (6). Additionally, they show marked abnormalities in cellular immune function with changes in the number and function of circulating T cells (7). All of these abnormalities are reversible by the subcutaneous administration of leptin (8-12).

In 1997 we reported two children (child A and child B), first cousins of Pakistani origin, who were homozygous for a frameshift mutation in the $o b$ gene that resulted in undetectable circulating leptin and a syndrome of hyperphagia and severe obesity (13). We subsequently reported marked improvements in hyperphagia and body fat mass in child A after 1 year of subcutaneous recombinant human leptin (r-metHuLeptin) therapy (14). We recently identified 
another unrelated leptin-deficient child (child C), also from a consanguineous family of Pakistani origin living in the United Kingdom. This child was homozygous for the same frameshift mutation $(\Delta G 133)$ that was reported previously in child A and B. The two families identified by us as carrying this mutation were not known to be related over at least five generations. We now report the results of leptin replacement therapy in these three children who were treated for periods ranging from 10 to 50 months. We have undertaken assessments of a range of physiological, endocrine, metabolic, and immune parameters, which allow cross-species comparison of the pleiotropic effects of leptin replacement.

\section{Methods}

Leptin administration and dosage. All studies were approved by the local ethical committee and were conducted in accordance with Declaration of Helsinki principles. All studies had full informed consent from the parents and children involved. R-metHuLeptin was administered as a once-daily subcutaneous injection. The initial dose was calculated to achieve $10 \%$ predicted serum leptin concentration based on age, gender, and percentage of body fat (calculations based on inhouse pharmacodynamic and pharmacokinetic data from AMGEN Inc., Thousand Oaks, California, USA). The dose administered (milligram per kilogram of lean body weight [LBW]) remained the same if weight stabilized or was reduced. If weight increased over two successive 2 -month periods, the dose was increased to achieve $20 \%$ and subsequently to 50,100 , and $150 \%$ predicted serum leptin concentration.

Body composition. Body composition was measured in all three subjects using whole-body dual-energy $\mathrm{x}$-ray absorptiometry (DXA) (QDR 1000W; Hologic Inc., Waltham, Massachusetts, USA) to determine bone mineral content, lean mass, and fat mass every 2 months (15).

Energy intake and expenditure. To assess the impact of leptin on ingestive behavior, child A, B, and C were given an ad libitum test meal after an overnight fast. Although we have reported previously an effect of leptin on ad libitum energy intake in child $A$, this was almost certainly an underestimate because before treatment the child consumed the entire $7-\mathrm{MJ}(1,670 \mathrm{kcal})$ meal (14). For this reason all further ad libitum intake studies were undertaken with an $18-\mathrm{MJ}(4,400 \mathrm{kcal})$ meal presented after an overnight fast. The contents of the ad libitum test meal were covertly weighed before and after consumption and total energy intake and macronutrient composition calculated using standard tables (16). Energy intake was expressed per kilogram LBW as a means of comparing intake between subjects of different age and body size.

Basal metabolic rate (BMR) was measured by indirect calorimetry (Europa Gas Exchange Monitor; Nutren Technology Ltd., Manchester, United Kingdom) after an overnight fast in a thermoneutral environment. Total energy expenditure was measured using doubly labeled $\left({ }^{2} \mathrm{H}^{18} \mathrm{O}\right)$ water (17).
Hormonal and metabolite assays. Blood samples were obtained after an overnight fast and analyzed for cholesterol, triglycerides, HDL cholesterol, LDL cholesterol, glucose, and insulin (Dade Behring Inc., Newark, Delaware, USA). Thyroid-stimulating hormone, free thyroxine, free tri-iodothyronine, adrenocorticotrophic hormone, cortisol measured at 0900, follicle-stimulating hormone (FSH), luteinizing hormone (LH), estradiol, and testosterone were measured using standard assays (Wallac Oy, Turku, Finland).

R-metHuLeptin pharmacokinetics. Serum leptin was measured using a solid-phase sandwich ELISA (AMGEN Inc.). Samples were taken before injection and at 4 hours after injection every 2 months.

Anti-r-metHuLeptin-neutralizing Ab bioassay. Samples identified as reactive in a screening immunoassay were tested for the presence of neutralizing Ab's to r-metHuleptin. The bioassay used the murine cell line $32 \mathrm{D}$ clone 4 that naturally expresses the murine IL-3 receptor and was engineered to express a chimeric receptor consisting of the extracellular leptin-binding domain and the transmembrane- and intracellularsignaling domains of the EPO receptor (32Dcl4 OBECA). Both leptin and murine IL-3 (mIL-3) independently induced proliferation of the OBECA cells. Samples were partially purified by using a $50-\mathrm{K}$ molecular-weight cut-off Microcon centrifugal filter device (Millipore Corp., Bedford, Massachusetts, USA) and were diluted 1:20 with assay media (RPMI1640 containing $2 \%$ FBS and $1 \times$ Pen-Strep/glutamine). The samples were centrifuged at $12,900 \mathrm{~g}$ for 15 minutes at $25^{\circ} \mathrm{C}$. The retentate was returned to the starting volume by addition of assay media. This centrifugation step was repeated. Fifty microliters of the final retentate were added to OBECA cells in the presence of $0.5 \mathrm{ng} / \mathrm{ml}$ leptin in the wells of a 96-well microplate. The final concentration of human serum in the well was $1.25 \%$. Samples and controls were allowed to incubate with the OBECA cells for 48 hours at $37^{\circ} \mathrm{C}$ at $5 \% \mathrm{CO}_{2}$ before addition of tritiated thymidine. The plates were incubated for an additional 4 hours before being harvested onto filter mats for counting on a Packard Matrix beta counter.

Samples that demonstrated more than 50\% inhibition of the response of the cells to $0.5 \mathrm{ng} / \mathrm{ml}$ leptin were considered reactive and tested for their ability to inhibit the response of the cells to $160 \mathrm{pg} / \mathrm{ml}$ recombinant mIL-3. A patient was considered positive for the development of neutralizing Ab's if (a) the post-dose sample inhibited the leptin-induced proliferation by equal to or greater than $50 \%$; (b) the ratio of pre-dose counts/post-dose counts was equal to or greater than 2.0; and (c) the post-dose sample did not inhibit the response of the cells to mIL-3.

Lymphocyte function. Flow cytometry was performed as described previously using a FACS scan flow cytometer and appropriate directly conjugated mAb's (Becton Dickinson-PharMingen, San Diego, California, USA). A panel of 15 normal 2- to 4-year-old children was used 
as the control population, and our data were found to be consistent with observations published previously. Analyses were performed on fresh lymphocytes at the time of sampling. $T$ cell cultures were performed in triplicate in microtiter 96-well round-bottomed plates (BD Biosciences, San Jose, California, USA). After passing blood through a Ficoll gradient (Pharmacia Biotech $\mathrm{AB}$, Uppsala, Sweden) peripheral blood leukocytes $\left(2 \times 10^{5} /\right.$ well $)$ were stimulated in parallel with the following stimuli: OKT3 $0.1 \mu \mathrm{g} / \mathrm{ml}$ (Ortho Diagnostic Systems Inc., Raritan, New Jersey, USA); $2 \mu \mathrm{g} / \mathrm{ml}$ phytohemagglutinin (PHA; Sigma Chemical, Milan, Italy); $0.01 \mu \mathrm{M}$ PMA and $0.5 \mu \mathrm{M}$ Ionomycin (Iono; Sigma Chemical); $10 \mu \mathrm{g} / \mathrm{ml}$ tuberculin purified protein derivitive (PPD) (Northern Serumin Institut, Copenhagen, Denmark). $T$ cell viability was assessed before each proliferative assay by trypan blue staining and was between 85 and $95 \%$. Lymphocytes were incubated for 72 hours at $37^{\circ} \mathrm{C}$ in RPMI-1640 medium (Gibco-BRL; Life Technologies Inc., Gaithersburg, Maryland, USA), supplemented with $2 \%(\mathrm{vol} / \mathrm{vol})$ of patient's autologous serum or autologous serum for controls, $2 \mathrm{mM}$ L-glutamine (Life Technologies Inc.), $0.1 \mathrm{mM}$ nonessential amino acids (Life Technologies Inc.), $1 \mathrm{mM}$ sodium pyruvate (Life Technologies Inc.), $100 \mathrm{U} / \mathrm{ml}$ penicillin, $100 \mu \mathrm{g} / \mathrm{ml}$ streptomycin (Life Technologies Inc.). Fortyeight to sixty hours after initiation cell culture, supernatants $(100 \mu \mathrm{l})$ were removed and frozen at $-80^{\circ} \mathrm{C}$ for cytokine assay. IFN- $\gamma$, IL-4, IL-10, and TGF- $\beta$ were measured by ELISA (PharMingen, San Diego, California, USA). The lower limits of detection for each assay were less than $2 \mathrm{pg} / \mathrm{ml}$ for IFN- $\gamma$, less than $0.6 \mathrm{pg} / \mathrm{ml}$ for IL-4, and less than $1 \mathrm{pg} / \mathrm{ml}$ for IL-10 and TGF- $\beta$. The remaining cells were incubated for an additional 16 hours, pulsed with $0.5 \mu \mathrm{Ci} /$ well of $[3 \mathrm{H}]$ thymidine (Amersham-Pharmacia Biotech, Buckinghamshire, United Kingdom), harvested on glass-fiber filters using a Tomtec Inc. (Orange, Connecticut, USA) 96-well cell harvester, and counted in a 1205 Betaplate liquid scintillation counter (Wallac Inc., Gaithersburg, Maryland, USA). Results are expressed as mean counts per minute plus or minus SD from triplicate cultures.

\section{Results}

Leptin induces sustained weight loss due to loss of fat mass. All three subjects lost weight within 2 weeks of initiation of r-metHuLeptin therapy (Figure 1a). Weight loss continued in all subjects throughout the trial, albeit with some refractory periods, which were overcome by increases in r-metHuLeptin dose (Figure 1b). At all time points more than $98 \%$ of the weight lost was represented by fat mass (Table 1). Lean mass increased in all children over the study period, in keeping with their increase in linear growth (18) (Table 1). This was most marked in the two youngest children, in whom the amount of fat-free mass that accrued was in keeping with that seen in normal children of this age $(18,19)$.

Leptin effects on energy intake and expenditure. In all three children there was a marked reduction in energy intake (range 45-84\%) at the test meal after 2 months of r-metHuLeptin therapy (Figure 2a). These findings are supported by parental reports of a marked amelioration in their hyperphagia.

With the continuation of $r$-metHuLeptin therapy, in all three children there were episodes during which fat mass was regained. In all instances this was preceded by a
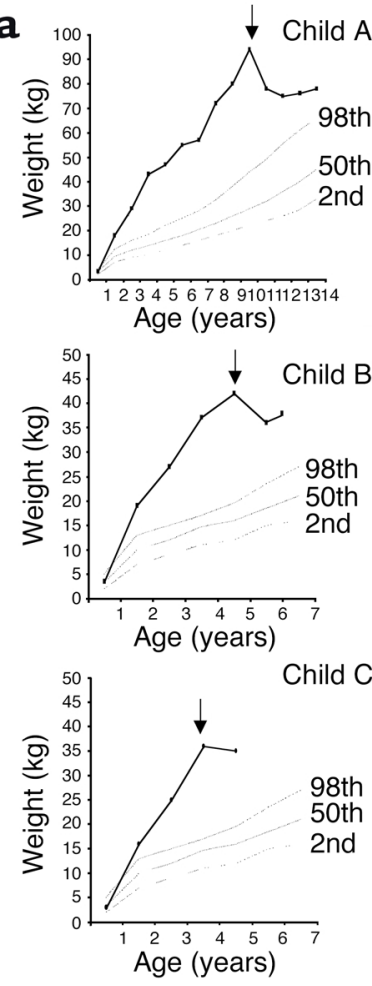

\section{b}
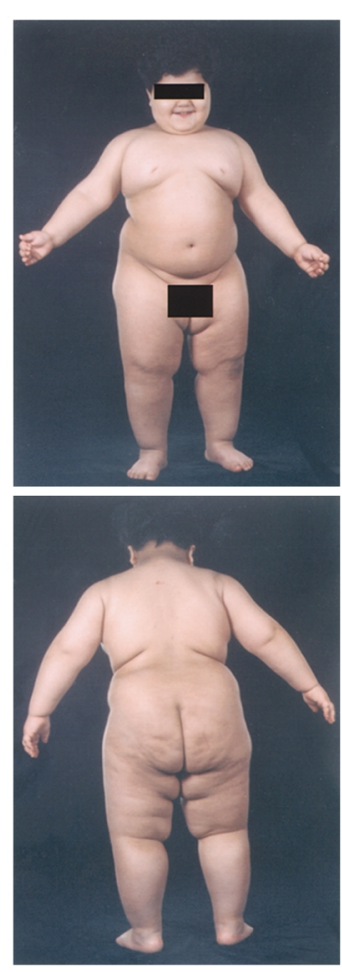
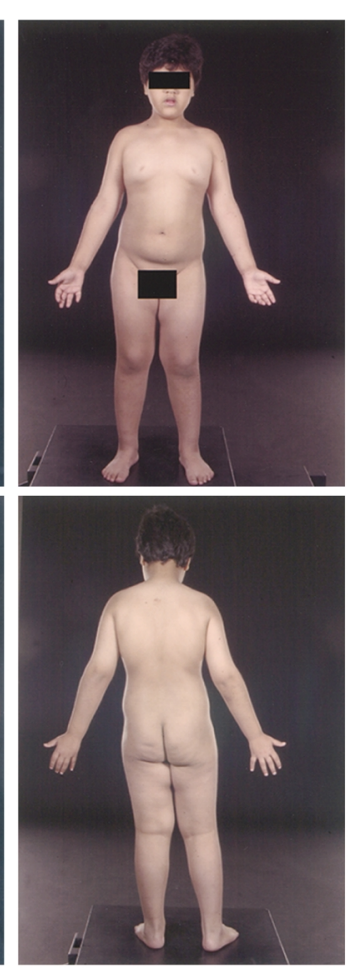

\section{Figure 1}

Effects of $r$-metHuLeptin on weight in three children with congenital leptin deficiency. (a) Weights of child A compared with normal centiles for girls and of child B and child C compared with normal centiles for boys. Arrows indicate the start of r-metHuLeptin therapy. (b) Clinical photographs of child $B$ before (height $=107 \mathrm{~cm}$ ) and 24 months after $r$-metHuLeptin therapy (height $=124 \mathrm{~cm})$ (reproduced with the permission of the child's parents). 


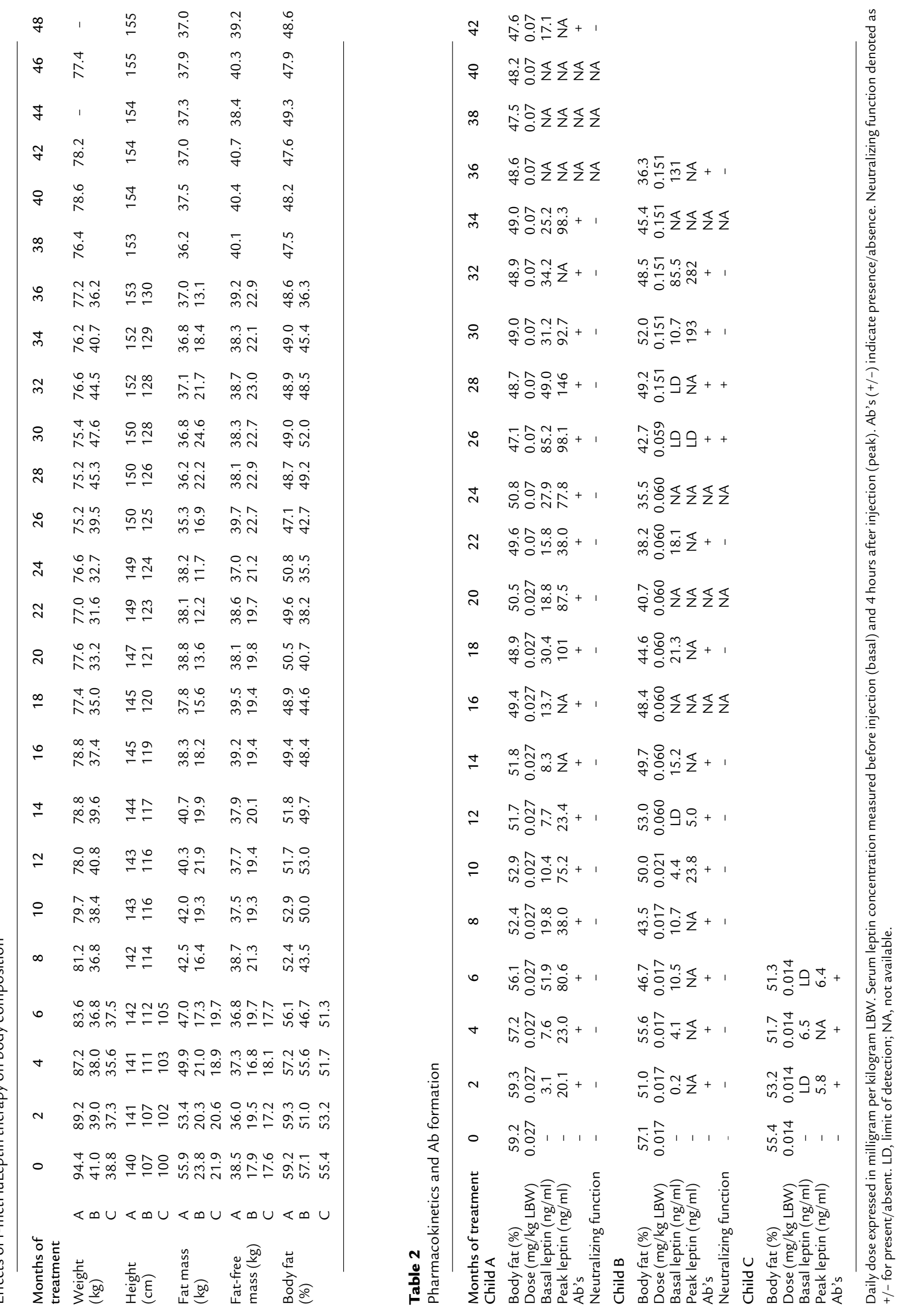



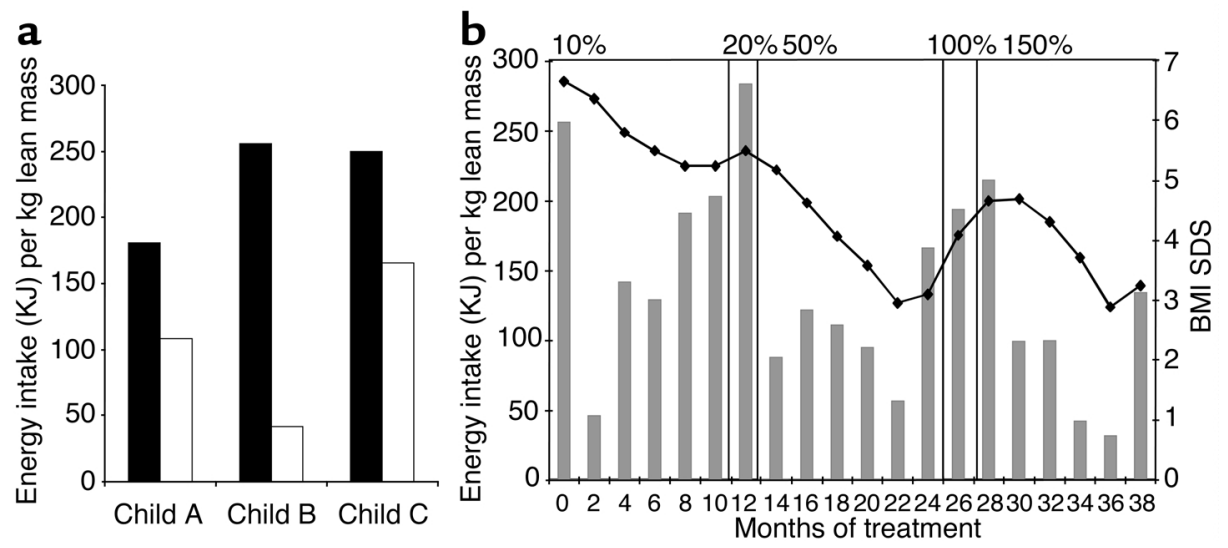

\section{Figure 2}

Effects of $r$-metHuLeptin therapy on energy intake. (a) Energy intake at an ad libitum test meal before (black bars) and 2 months after (white bars) $r$-metHuLeptin therapy in child A, B, and C. Energy intake (KJ) expressed per kilogram lean body mass to compare intake of subjects of different age and body size. (b) Changes in body mass index SDS (BMI SDS) (filled symbols) and energy intake at an 18-MJ ad libitum test meal (gray bars) during 36 months of treatment in child B. Panels indicate duration of $r$-metHuLeptin dose expressed as a percentage of predicted serum leptin concentration based on age, gender, and body composition.

parental reports of the return of hyperphagia 2 to 4 weeks before the documented weight gain. In each instance the reported hyperphagia was supported by the results at the ad libitum test meal (Figure $2 b$; data for child B). In at least one instance an episode of refractoriness to therapy coincided with the transient appearance of neutralizing Ab's (see below). In each case an increase in dose of leptin (Table 2) led to a decrease in hyperphagia, reduced food intake at the test meal, and loss of fat mass after a period of approximately 4 weeks.

Measurements of energy expenditure were performed on the two children (child A and child B) who were able to tolerate the methods used. There was no significant change in BMR adjusted for lean mass between baseline and 1 or 2 months of $r$-metHuLeptin therapy in child $A$ or child B (Table 3). Adjusted BMR remained unchanged over the subsequent 42 months in child $\mathrm{A}$ and 28 months in child B. To assess whether leptin might have acute effects on metabolic rate, BMR was measured daily for the first 3 days after the start of $r$-metHuLeptin therapy in child $B$ with no differences from baseline values being observed (data not shown). Free-living or total energy expenditure (TEE) was measured using doubly labeled water in these two children. In child A, there was no change in TEE adjusted per kilogram of lean mass before and after r-metHuLeptin treatment; similar observations were made in child $B$ after adjusting for changes in body composition (Table 3 ).

Metabolic and endocrine effects of $r$-metHuLeptin therapy. All three children had normal fasting plasma glucose values before treatment but all had hyperinsulinemia, which was consistent with their age and degree of obesity (ranges for severely obese children established in more than 400 subjects: $29-183 \mathrm{pmol} / \mathrm{l}$ for 3 year olds

Table 3

Effects of r-metHuLeptin therapy on energy expenditure

\begin{tabular}{|c|c|c|c|c|c|c|c|c|c|c|c|c|c|c|c|c|c|c|c|c|c|c|}
\hline $\begin{array}{l}\text { Months of } \\
\text { treatment }\end{array}$ & 0 & 2 & 4 & 6 & 8 & 10 & 12 & 14 & 16 & 18 & 20 & 22 & 24 & 26 & 28 & 30 & 32 & 34 & 36 & 38 & 40 & 42 \\
\hline \multicolumn{23}{|l|}{ Child A } \\
\hline $\begin{array}{l}\text { BMR } \\
\text { (MJ/day) }\end{array}$ & 7.7 & 7.1 & 7.4 & 6.8 & 6.9 & 6.8 & 6.3 & 6.4 & - & - & - & 6.0 & 6.5 & 6.4 & 7.0 & - & - & - & 6.8 & 6.9 & 6.8 & 6.9 \\
\hline $\begin{array}{l}\text { BMR/kg LBW } \\
\text { (MJ/kg/day) }\end{array}$ & 0.21 & 0.21 & 0.21 & 0.19 & 0.19 & 0.19 & 0.17 & 0.18 & - & - & - & 0.16 & 0.19 & 0.17 & 0.19 & - & - & - & 0.18 & 0.18 & 0.180 & 0.18 \\
\hline TEE (MJ/day) & 12.4 & - & - & 11.1 & - & - & 12.3 & - & - & 12.2 & - & - & - & 11.5 & - & 13.5 & - & - & 10.1 & - & - & - \\
\hline $\begin{array}{l}\text { TEE/kg LBW } \\
\text { (MJ/kg/day) }\end{array}$ & 0.33 & - & - & 0.32 & - & - & 0.34 & - & - & 0.33 & - & - & - & 0.30 & - & 0.37 & - & - & 0.26 & - & - & - \\
\hline \multicolumn{23}{|l|}{ Child B } \\
\hline $\begin{array}{l}\text { BMR } \\
\text { (MJ/day) }\end{array}$ & 4.5 & 4.7 & 3.9 & 5.0 & 5.0 & 5.2 & 5.4 & 5.1 & 4.1 & 3.7 & 5.2 & 3.8 & 4.5 & 4.9 & 5.0 & & & & & & & \\
\hline $\begin{array}{l}\text { BMR/kg LBW } \\
\text { (MJ/kg/day) }\end{array}$ & 0.26 & 0.25 & 0.24 & 0.26 & 0.26 & 0.28 & 0.29 & 0.27 & 0.22 & 0.20 & 0.27 & 0.20 & 0.22 & 0.23 & 0.23 & & & & & & & \\
\hline TEE (MJ/day) & 7.4 & - & - & 6.4 & - & - & 7.4 & - & - & - & 6.4 & & & & & & & & & & & \\
\hline $\begin{array}{l}\text { TEE/kg LBW } \\
\text { (MJ/kg/day) }\end{array}$ & 0.42 & - & - & 0.33 & - & - & 0.40 & - & - & - & 0.34 & & & & & & & & & & & \\
\hline
\end{tabular}


a

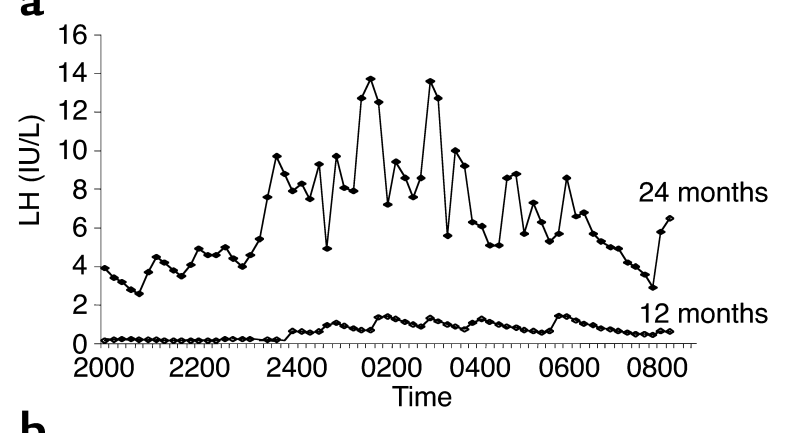

b

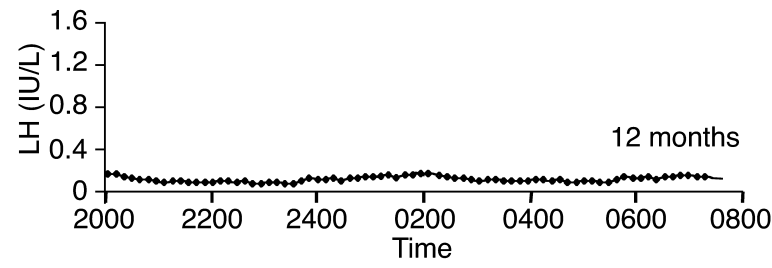

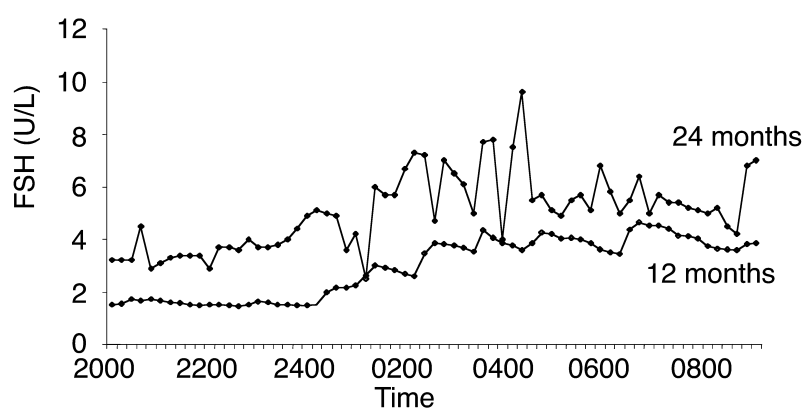

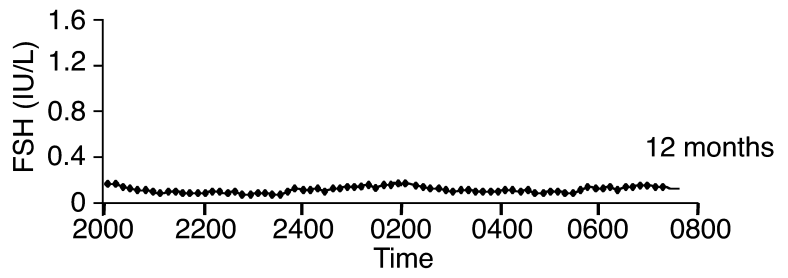

Figure 3

Leptin therapy results in pubertal development at an appropriate developmental age. (a) Pulsatile secretion of LH and FSH in child A after 12 and 24 months of r-metHuLeptin therapy. (b) No pulsatile secretion after 12 months of treatment in child B.

with a BMI SD score $[\mathrm{SDS}]=5-7 ; 46-244 \mathrm{pmol} / \mathrm{l}$ for 9 year olds with BMI SDS $=5$ ) (personal observations). Plasma insulin concentrations did not fall acutely after initiation of r-metHuLeptin treatment, but rather a steady and consistent reduction in fasting plasma insulin was observed in keeping with the gradual loss of fat mass (Table 4). Similarly, in response to r-metHuLeptin therapy, serum cholesterol, triglycerides, and LDL cholesterol levels gradually reduced and serum HDL cholesterol increased in all three subjects.

In all three children growth was not stunted in the untreated state and continued along predicted centiles throughout the course of treatment (Table 1 and data not shown). Plasma IGF-1 levels were within the normal age-related reference range before treatment and increased appropriately with age (Table 5). Wholebody bone mineral content (BMC) and bone mineral density (BMD) were appropriate for age and gender in the leptin-deficient state (data not shown), although skeletal maturation (assessed using radiographs of the left hand and wrist) was increased by a mean of 2.1 years. After treatment, BMC, BMD, and skeletal maturation increased in line with normal age-related development in all three children (data not shown).

Urinary free cortisol levels were normal and not significantly changed by leptin administration in child A. The two younger children were unable to undertake 24-hour urine collections, but 0900-hour cortisol

Table 4

Effects of r-metHuLeptin therapy on metabolic parameters

\begin{tabular}{|c|c|c|c|c|c|c|c|c|c|}
\hline Months of treatment & & 0 & 6 & 12 & 18 & 24 & 30 & 36 & 42 \\
\hline \multirow[t]{3}{*}{ Insulin (0-60 pmol/l) } & $A$ & 291 & 381 & 86 & 83 & 66 & - & - & 33 \\
\hline & B & 162 & 90 & - & 86 & 46 & - & 60 & \\
\hline & $C$ & 201 & 147 & & & & & & \\
\hline \multirow[t]{3}{*}{ Glucose (3.5-5.5 mmol/l) } & $A$ & 4.3 & 5.0 & 4.7 & 4.6 & 4.5 & 4.6 & 4.5 & 5.0 \\
\hline & B & 4.0 & 4.6 & 5.2 & 4.8 & 4.3 & - & 4.3 & \\
\hline & $C$ & 4.0 & 4.4 & & & & & & \\
\hline \multirow[t]{3}{*}{ Total cholesterol $(\mathrm{mmol} / \mathrm{l})$} & $A$ & 5.0 & 4.3 & 4.7 & 4.7 & 4.3 & 4.3 & 4.2 & - \\
\hline & B & 4.4 & 4.2 & 3.8 & 3.4 & 3.9 & - & 2.9 & \\
\hline & $C$ & 5.2 & 4.4 & & & & & & \\
\hline \multirow[t]{3}{*}{ LDL cholesterol $(\mathrm{mmol} / \mathrm{l})$} & $A$ & 3.4 & 3.1 & 2.9 & 3.0 & 2.8 & 2.8 & 2.3 & - \\
\hline & B & 3.1 & 2.4 & 2.2 & 2.2 & 2.1 & - & 1.8 & \\
\hline & $C$ & 3.4 & 2.5 & & & & & & \\
\hline \multirow[t]{3}{*}{ Triglycerides (mmol/l) } & $A$ & 1.3 & 1.0 & 1.5 & 0.9 & 0.8 & 0.7 & 1.2 & - \\
\hline & B & 1.3 & 2.1 & 1.6 & 0.7 & 0.7 & - & 0.6 & \\
\hline & $C$ & 2.0 & 2.1 & & & & & & \\
\hline \multirow[t]{3}{*}{ HDL cholesterol $(\mathrm{mmol} / \mathrm{l})$} & A & 1.1 & 0.8 & 1.2 & 1.3 & 1.2 & 1.2 & 1.4 & - \\
\hline & B & 0.8 & 0.9 & 0.9 & 0.9 & 1.5 & - & 0.9 & \\
\hline & $\mathrm{C}$ & 1.0 & 1.0 & & & & & & \\
\hline
\end{tabular}


Table 5

Effects of r-metHuLeptin therapy on endocrine physiology

\begin{tabular}{|c|c|c|c|c|c|c|c|c|c|c|}
\hline $\begin{array}{l}\text { Months of } \\
\text { treatment }\end{array}$ & & 0 & 2 & 6 & 12 & 18 & 24 & 30 & 36 & 42 \\
\hline $\begin{array}{l}\text { TSH } \\
(0.4-4.0 \mathrm{mU} / \mathrm{l})\end{array}$ & $\begin{array}{l}\text { A } \\
\text { B } \\
\text { C }\end{array}$ & $\begin{array}{l}2.8 \\
2.7 \\
3.3\end{array}$ & $\begin{array}{l}3.2 \\
4.0 \\
5.2\end{array}$ & $\begin{array}{l}4.5 \\
3.9 \\
3.8\end{array}$ & $\begin{array}{l}2.3 \\
3.9\end{array}$ & $\begin{array}{c}3.2 \\
-\end{array}$ & $\begin{array}{l}2.7 \\
3.9\end{array}$ & $\begin{array}{l}1.3 \\
-\end{array}$ & $\begin{array}{l}3.1 \\
3.3\end{array}$ & 2.2 \\
\hline $\begin{array}{l}\text { fT4 } \\
(9-20 \mathrm{pmol} / \mathrm{l})\end{array}$ & $\begin{array}{l}\text { A } \\
\text { B } \\
\text { C }\end{array}$ & $\begin{array}{c}11.8 \\
12.0 \\
9.9\end{array}$ & $\begin{array}{l}13.8 \\
15.4 \\
12.0\end{array}$ & $\begin{array}{l}14.1 \\
15.5 \\
12.3\end{array}$ & $\begin{array}{l}14.0 \\
14.7\end{array}$ & $\begin{array}{c}15.2 \\
-\end{array}$ & $\begin{array}{l}14.1 \\
16.4\end{array}$ & $\begin{array}{c}13.8 \\
-\end{array}$ & $\begin{array}{l}14.3 \\
14.2\end{array}$ & 14.4 \\
\hline $\begin{array}{l}\text { fT3 } \\
(3.0-7.5 \mathrm{pmol} / \mathrm{l})\end{array}$ & $\begin{array}{l}\text { A } \\
\text { B } \\
\text { C }\end{array}$ & $\begin{array}{l}6.5 \\
5.5 \\
6.6\end{array}$ & $\begin{array}{c}7.2 \\
9.4 \\
10.0\end{array}$ & $\begin{array}{l}5.5 \\
8.5 \\
7.8\end{array}$ & $\begin{array}{l}5.7 \\
9.2\end{array}$ & $\begin{array}{l}7.4 \\
8.5\end{array}$ & $\begin{array}{l}7.6 \\
6.6\end{array}$ & 7.7 & 7.4 & - \\
\hline $\begin{array}{l}0900 \text { cortisol } \\
(280-650 \mathrm{nmol} / \mathrm{l})\end{array}$ & $\begin{array}{l}\text { A } \\
B \\
C\end{array}$ & $\begin{array}{l}420 \\
156 \\
195\end{array}$ & $\begin{array}{l}388 \\
328 \\
142\end{array}$ & $\begin{array}{l}484 \\
218 \\
158\end{array}$ & $\begin{array}{l}290 \\
462\end{array}$ & $\begin{array}{l}337 \\
192\end{array}$ & $\begin{array}{l}295 \\
171\end{array}$ & 178 & 211 & - \\
\hline IGF-1 (IU/I) & $\begin{array}{l}\text { A } \\
B \\
C\end{array}$ & $\begin{array}{c}19.1 \\
8.2 \\
5.0\end{array}$ & $\begin{array}{l}- \\
- \\
-\end{array}$ & $\begin{array}{c}24.0 \\
- \\
-\end{array}$ & $\begin{array}{l}28.0 \\
13.9\end{array}$ & $\begin{array}{l}- \\
-\end{array}$ & $\begin{array}{l}44.0 \\
15.9\end{array}$ & - & $\begin{array}{l}75.0 \\
21.0\end{array}$ & - \\
\hline $\mathrm{FSH}(\mathrm{mU} / \mathrm{I})$ & $\begin{array}{l}A \\
B \\
C\end{array}$ & $\begin{array}{l}0.2 \\
0.2 \\
0.2\end{array}$ & $\begin{array}{c}0.7 \\
- \\
-\end{array}$ & $\begin{array}{l}2.8 \\
0.2 \\
0.2\end{array}$ & $\begin{array}{l}2.9 \\
0.2\end{array}$ & $\begin{array}{l}4.3 \\
-\end{array}$ & $\begin{array}{l}5.3 \\
0.2\end{array}$ & $\begin{array}{c}4.9 \\
-\end{array}$ & $\begin{array}{l}4.9 \\
0.2\end{array}$ & $\begin{array}{l}- \\
-\end{array}$ \\
\hline $\mathrm{LH}(\mathrm{mU} / \mathrm{I})$ & $\begin{array}{l}\text { A } \\
\text { B } \\
\text { C }\end{array}$ & $\begin{array}{l}0.2 \\
0.2 \\
0.2\end{array}$ & $\begin{array}{c}0.2 \\
0.2 \\
-\end{array}$ & $\begin{array}{l}0.3 \\
0.2 \\
0.2\end{array}$ & $\begin{array}{l}0.3 \\
0.2\end{array}$ & $\begin{array}{c}1.7 \\
-\end{array}$ & $\begin{array}{l}2.4 \\
0.2\end{array}$ & $\begin{array}{c}4.5 \\
-\end{array}$ & $\begin{array}{l}6.4 \\
0.2\end{array}$ & - \\
\hline $\begin{array}{l}\text { Estradiol } \\
(\mathrm{pmol} / \mathrm{l})\end{array}$ & A & 67 & 34 & 68 & 51 & 60 & 57 & 108 & 126 & 105 \\
\hline $\begin{array}{l}\text { Testosterone } \\
(\mathrm{nmol} / \mathrm{I})\end{array}$ & B & $\begin{array}{l}0.2 \\
0.2\end{array}$ & - & $\begin{array}{l}0.2 \\
0.2\end{array}$ & 0.2 & - & 0.2 & - & 0.2 & \\
\hline
\end{tabular}

Age-specific ranges for IGF-1: 2.5-20 IU/I (0-7 years), 4.5-37.5 IU/I (7-10 years), 7-50 IU/I (10-11 years), 8.5-60 IU/I (11-12 years), 10-75 IU/I (12-13 years) Prepubertal ranges of gonadotropins and sex steroids: FSH $(<0.2 \mathrm{mU} / \mathrm{I}), \mathrm{LH}(<0.2 \mathrm{mU} / \mathrm{I})$, estradiol $(<80 \mathrm{pmol} / \mathrm{I})$, and testosterone $(<0.5 \mathrm{nmol} / \mathrm{I})$. Females in the follicular phase of the menstrual cycle: FSH (2.9-8.4 mU/I), LH (1.3-8.4 mU/I), estradiol (100-750 pmol/I).

measurements were in the normal range in child $\mathrm{A}, \mathrm{B}$, and $\mathrm{C}$ before and after $\mathrm{r}$-metHuLeptin administration (Table 5). Although thyroid function tests were within the normal range before the start of r-metHuLeptin therapy, free thyroxine levels were significantly increased compared with baseline in all three children at their first post-treatment measurement ( 2 months) and subsequently remained constant (Table 5). The mean $( \pm \mathrm{SD})$ concentrations of free thyroxine pre- and post-r-metHuLeptin therapy were $11.2( \pm 1.1)$ and 14.3 $( \pm 1.1) \mathrm{pmol} / \mathrm{l}$, respectively $(P<0.05$, paired Student $t$ test). Plasma tri-iodothyronine (fT3) concentrations rose after leptin administration in child $\mathrm{B}$ and $\mathrm{C}$ but not in child A. There was no significant change in plasma concentrations of thyrotropin (TSH) (Table 5).

In the two prepubertal children, basal FSH and $\mathrm{LH}$ concentrations and sex steroid concentrations remained in the prepubertal range after a maximum of 36 months of r-metHuLeptin therapy (Table 5). In contrast, there was a gradual increase in gonadotropins and estradiol in child A, and after 24 months of r-metHuLeptin therapy, child A (age 11

Table 6

Effects of $r$-metHuLeptin replacement therapy on T cell subpopulations

\begin{tabular}{|c|c|c|c|c|c|c|c|}
\hline Cell type & $\begin{array}{c}-10 \\
\left(\text { cell } / \mathrm{mm}^{3}\right) \\
(\%)\end{array}$ & -6 & 0 & +2 & +6 & +10 & $\begin{array}{c}\text { Normal range } \\
\left(\text { cell/ } \mathrm{mm}^{3}\right) \\
(\%)\end{array}$ \\
\hline $\mathrm{CD}^{+}$ & $\begin{array}{c}2,328 \\
(56)\end{array}$ & $\begin{array}{c}2,686 \\
(49)\end{array}$ & $\begin{array}{c}2,416 \\
(58)\end{array}$ & $\begin{array}{c}1,893 \\
(51)\end{array}$ & $\begin{array}{c}3,262 \\
(72)\end{array}$ & $\begin{array}{c}3,087 \\
(66)\end{array}$ & $\begin{array}{c}1,200-2,500 \\
(65-82)\end{array}$ \\
\hline $\mathrm{CD}^{+}$ & $\begin{array}{l}815 \\
(19)\end{array}$ & $\begin{array}{l}750 \\
(18)\end{array}$ & $\begin{array}{l}866 \\
(21)\end{array}$ & $\begin{array}{l}927 \\
(24)\end{array}$ & $\begin{array}{l}1,468 \\
(31)\end{array}$ & $\begin{array}{l}1,358 \\
(29)\end{array}$ & $\begin{array}{c}1,000-2,000 \\
(35-50)\end{array}$ \\
\hline $\mathrm{CD}^{+}$ & $\begin{array}{l}1,410 \\
(25)\end{array}$ & $\begin{array}{c}1,836 \\
(26)\end{array}$ & $\begin{array}{l}1,450 \\
(25)\end{array}$ & $\begin{array}{l}850 \\
(22)\end{array}$ & $\begin{array}{l}1,468 \\
(31)\end{array}$ & $\begin{array}{c}1,543 \\
(33)\end{array}$ & $\begin{array}{c}240-1,000 \\
(25-35)\end{array}$ \\
\hline $\mathrm{CD} 9^{+}$ & $\begin{array}{c}1,560 \\
(35)\end{array}$ & $\begin{array}{c}2,189 \\
(31)\end{array}$ & $\begin{array}{l}1,525 \\
(37)\end{array}$ & $\begin{array}{c}1,468 \\
(38)\end{array}$ & $\begin{array}{l}1,247 \\
(26)\end{array}$ & $\begin{array}{c}1,216 \\
(26)\end{array}$ & $\begin{array}{c}200-400 \\
(8-15)\end{array}$ \\
\hline $\mathrm{CD}^{-} / \mathrm{CD} 16^{+} / \mathrm{CD} 6^{+}$ & $\begin{array}{l}282 \\
(5)\end{array}$ & $\begin{array}{l}636 \\
(9)\end{array}$ & $\begin{array}{l}289 \\
(7)\end{array}$ & $\begin{array}{l}464 \\
(12)\end{array}$ & $\begin{array}{l}240 \\
(5)\end{array}$ & $\begin{array}{l}374 \\
(8)\end{array}$ & $\begin{array}{c}212-318 \\
(7-23)\end{array}$ \\
\hline $\mathrm{CD}^{+} / \mathrm{CD}^{+}$ratio & 0.57 & 0.40 & 0.59 & 1.09 & 1.0 & 0.88 & $1.0-2.6$ \\
\hline
\end{tabular}

Data represent the absolute number (relative percentage) of T cell subpopulations before $(-)$ and after $(+)$ starting leptin treatment in child $C$. 
a

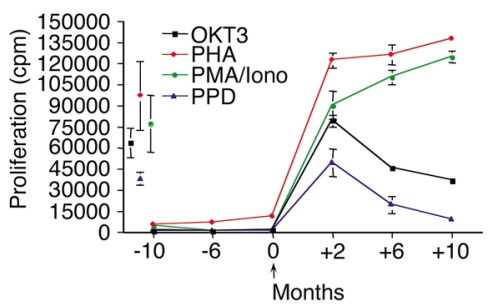

b
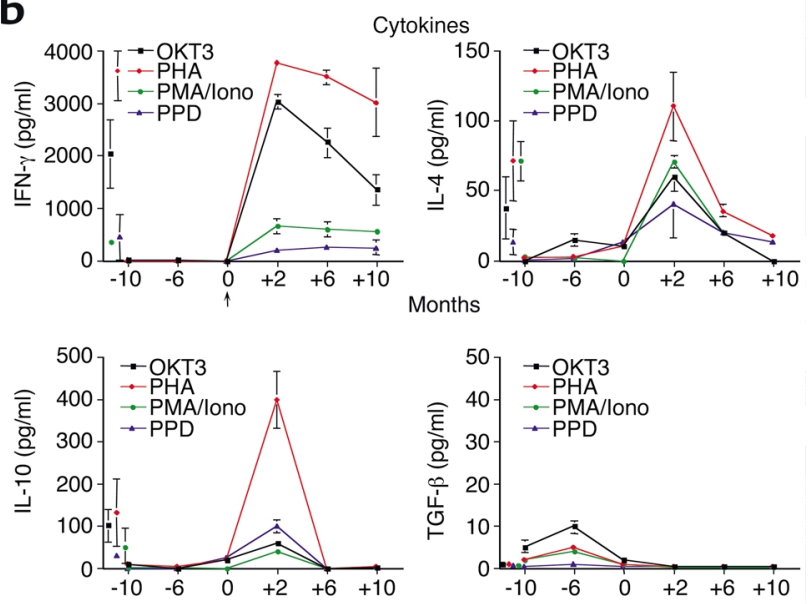

\section{Figure 4}

Effect of $r$-metHuLeptin on T cell proliferation and cytokine production in child C. (a) Proliferative responses of peripheral lymphocytes to T cell-specific stimuli at three different time points before (-) and after $(+)$ recombinant leptin treatment. All data are from triplicate cultures and expressed as mean \pm SD. Proliferative responses from normal agematched controls were measured in parallel experiments (mean shown as single point $\pm S D$ ). (b) Cytokine profiles in child $C$ at three different time points before $(-)$ and after $(+)$ recombinant leptin treatment. Cytokine measurements from normal age-matched controls were measured in parallel experiments (mean shown as single point \pm SEM).

years) had multiple synchronous nocturnal pulses of LH and FSH (Figure 3a). She subsequently progressed through the clinical stages of pubertal development, which was associated with a growth spurt, behavioral changes associated with pubertal development, enlargement of the ovaries on ultrasound with observation of follicles, and an increase in uterine size. She had her first menstrual period at 12.1 years and now has regular menstrual cycles; at age 13.6 years she has reached Tanner stage III. In contrast, after 12 months of r-metHuLeptin therapy, there was no evidence for pulsatile secretion of gonadotropins in child B at age 4.9 years (Figure $3 \mathrm{~b}$ ).

The effect of leptin on $T$ cell subset number and function. In all three children there was a clinical history before treatment of frequent childhood infections (predominantly of the upper respiratory tract) when compared with their wild-type siblings. There were no gross abnormalities of thermoregulation reported, with the children being able to mount a pyrexial response to infection. Of note, prior to treatment all children were reported to show the normal reduction in appetite when suffering from an acute infective illness. We analyzed the immunophenotype and $\mathrm{T}$ cell responses in freshly isolated cells before and after $\mathrm{r}$-metHuLeptin therapy in child $\mathrm{C}$ and undertook similar studies in frozen lymphocytes from child B.

Child $\mathrm{C}$ had a normal total lymphocyte number and a normal number of $\mathrm{CD}^{+} \mathrm{T}$ cells, but there was a reduction in $\mathrm{CD}^{+} \mathrm{T}$ cell number and an increase in $\mathrm{CD}^{+}$and $\mathrm{B}$ cells, causing a marked reduction in the $\mathrm{CD}^{+} / \mathrm{CD}^{+}$ratio (Table 6$)$. The absolute number of naive $\left(\mathrm{CD}^{+} \mathrm{CD}^{2} 5 \mathrm{RA}^{+}\right) \quad \mathrm{T}$ cells was reduced $(193.6 \pm 16.3,17.0 \% \pm 3.0 \%$, vs. $1,789.0 \pm 219.0$, $80.4 \% \pm 8.7 \%$, in controls) and consistently lower than that of memory $\left(\mathrm{CD} 4^{+} \mathrm{CD} 45 \mathrm{RO}^{+}\right) \mathrm{T}$ cells $(676.6 \pm 31.3$, $82.1 \% \pm 8.1 \%$, vs. $366.6 \pm 219.4,17.8 \% \pm 9.0 \%$, in controls), as was the naive/memory $\mathrm{T}$ cell ratio ( 0.28 vs. 4.88 in controls). R-metHuLeptin therapy normalized the immunophenotype in child $\mathrm{C}$. Thus, $\mathrm{CD}^{+} \mathrm{T}$ cell number was increased to a normal level as was the $\mathrm{CD}^{+} / \mathrm{CD}^{+} \mathrm{T}$ cell ratio, while the number of $\mathrm{CD}^{+}$and $\mathrm{CD} 19^{+} \mathrm{B}$ cells was reduced (Table 6). During the period of $\mathrm{r}$-metHuLeptin therapy, the number of naive $\mathrm{CD}^{+} \mathrm{CD} 45 \mathrm{RA}^{+} \mathrm{T}$ cells and the naive/memory $\mathrm{T}$ cell ratio were increased $(410.6 \pm 78.4$ and 0.48 , respectively). Finally, the proportion of NK cells, as defined by $\mathrm{CD}^{-} / \mathrm{CD} 16^{+} / \mathrm{CD} 56^{+}$expression, was normal and maintained constant before and after leptin treatment (Table 6), as was the expression of the $\gamma \delta^{+} \mathrm{T}$ cells (range $3-5 \%$, data not shown).

Prior to r-metHuLeptin therapy, lymphocytes from both patients showed reduced proliferative responses and lower production of cytokines to a variety of polyclonal stimuli such as OKT3, PHA, PMA/Iono, and the recall antigen PPD (Figure 4a for child C; child B data not shown). The $\mathrm{T}$ cell hyporesponsiveness persisted even when further stimuli were added (IL-2, anti-CD28 $\mathrm{mAb}$, allogeneic stimulator cells). Immunoglobulin levels were within the normal age-related range before treatment, with slightly increased IgM (data not shown), which is in agreement with data from $o b / o b$ mice (20). Similar observations were made for child B (data not shown).

In the leptin-deficient state, secretion of the proinflammatory cytokine IFN- $\gamma$ was completely suppressed. The absence of this Th1 cytokine was accompanied by impaired but detectable secretion of the Th2/regulatory cytokines IL-4, IL-10, and elevation of TGF- $\beta$. Intracellular cytofluorimetric (FACS) analysis of $T$ cells after PMA/Iono stimulation confirmed IL-4 and IL-10 secretion before treatment and undetectable staining for IFN- $\gamma$ (not shown). Chronic leptin replacement increased the proliferative responses and cytokine production of the patient's lymphocytes in all assays, in some even to a level comparable with lymphocytes from age-matched controls (Figure 4b). The most significant and best-maintained increases after treatment were observed in the production of IFN- $\gamma$, which was restored to a level similar to that of control cells (Figure 4c). Significant increases in the levels of IL-4 and IL-10 were also observed after 2 months of 
r-metHuLeptin therapy, although the levels were not always maintained (Figure $4 c$ ). TGF- $\beta$ secretion was completely suppressed to normal levels following the commencement of r-metHuLeptin therapy. Similar observations were made for child B (data not shown).

\section{Discussion}

These studies demonstrate that the subcutaneous administration of r-metHuLeptin is an effective, longterm therapy for children with congenital leptin deficiency. Leptin treatment in $a b / o b$ mice results in dramatic and selective loss of fat mass due to a combination of decreased food intake and increased energy expenditure (8-10). In humans, a similarly selective loss of fat mass is seen, with beneficial clinical and social outcomes for the treated children. The major impact of leptin on human energy balance was mediated by its suppressive effects on food intake, with a marked reduction in caloric consumption during a test meal. These effects were seen at a dose equivalent to $10 \%$ predicted serum leptin concentration $(0.01$ $\mathrm{mg} / \mathrm{kg} \mathrm{LBW}$ ) in contrast to the supraphysiological doses (0.1-0.3 mg/ $\mathrm{kg}$ body weight) required to induce weight loss in leptin-sufficient obesity (21). The $o b / o b$ mice are more sensitive to the anorectic effects of leptin compared with diet-induced obese mice, an effect that may be explained by increased hypothalamic expression of the signaling form of the leptin receptor (22). The effects of leptin were highly selective for fat mass, and the treated children grew normally and showed normal increases in lean mass during the course of the treatment. Leptin therapy produced a marked decrease in the amount of food ingested at an ad libitum test meal in all children, and this was associated with parental reports of a near normalization of eating behavior in the domestic setting. Fluctuations in body fat mass during therapy correlated strongly with alterations in food intake.

In contrast to the dramatic effects of leptin on human energy intake, we were unable to demonstrate a major effect of leptin on basal metabolic rate or free-living energy expenditure. Because weight loss by other means is reported to be associated with a fall in $\operatorname{BMR}(23,24)$, the failure of decline in energy expenditure in these subjects may, in itself, be significant. Activity-related energy expenditure, the energy expended during physical activity and skeletal muscle efficiency, which are altered in normal obese subjects after weight loss (25), were not measured. We cannot exclude effects on these parameters and on diet-induced thermogenesis, which may be significant at the levels of energy intake seen in untreated leptin deficiency. While the absence of measurable direct effects on energy expenditure may reflect an innate difference between humans and rodents, it is noteworthy that even in rodents the effects of leptin deficiency on energy expenditure and thermogenesis are highly dependent on the thermal conditions under which these measurements are taken (4). For ethical reasons we were unable to explore the effects of cold challenge in human leptin deficiency, either in the treated or untreated state.

The administration of $\mathrm{r}$-metHuLeptin resulted in a steady and marked fall in plasma insulin concentrations and a reduction in serum cholesterol and triglycerides in all three children, whereas HDL-cholesterol concentrations increased. Although, in rodents, leptin administration has been demonstrated to have acute beneficial effects on insulin sensitivity (26), the fall in plasma insulin in these children was delayed and appeared to parallel the reduction in fat mass. The improvement in serum lipids was similarly gradual. While these observations do not exclude an acute effect of leptin per se on insulin sensitivity and lipid metabolism, the effect of loss of fat mass appears to dominate in humans.

We have commented previously on the marked difference between mice and humans in the effects of leptin deficiency on both the hypothalamic-pituitary-adrenal axis and on linear growth (14). The extended data set represented by the studies reported herein confirms the lack of any major impact of leptin deficiency on these endocrine functions in humans, in contrast with mice. Our findings do, however, support the notion that the hypothalamic-pituitary thyroidal axis can be influenced by leptin in a relatively acute manner. Thus, free thyroxine levels, although being in the normal range before treatment, consistently showed an increase at the earliest post-treatment time point and subsequently stabilized at that new state. In contrast, weight loss by other means is well recognized to be associated with a fall in concentrations of thyroid hormones (27). These findings are consistent with evidence from animal models that leptin profoundly influences TRH release from the hypothalamus $(28,29)$ and with recent data that leptin administration can blunt the fall in free thyroxine concentrations induced by weight loss in previously weightstable subjects (30). Leptin may also regulate TSH pulsatility as has been suggested by a previous study of an adult leptin-deficient subject (31). The rapid increase in $\mathrm{fT} 4$ was accompanied by a similar increase in $\mathrm{fT} 3$ in the two youngest, but not the oldest child. Currently, we cannot explain this divergent response, but it may conceivably relate to age-dependent effects of leptin on thyroid hormone deiodination (32).

The presence of adequate circulating levels of leptin are clearly essential for the activation of the hypothalamic-pituitary-gonadal axis at puberty because adults with congenital leptin deficiency $(33,34)$ and leptin receptor mutations (35) fail to undergo pubertal development. Our findings in child A, who, prior to treatment, was prepubertal despite a bone age of 12.5 years, demonstrates conclusively that leptin replacement can facilitate the entire repertoire of pubertal development. Some studies have suggested that an increment of plasma leptin may be involved in the initiation of puberty (36). There was, therefore, at least a theoretical concern that leptin replacement in young leptin-deficient children might initiate precocious puberty. There was no 
clinical or biochemical evidence for this in the younger children in this study. In particular, the detailed studies of LH and FSH pulsatility undertaken in child B after 12 months of leptin therapy demonstrated the maintenance of an entirely prepubertal pattern of gonadotropin secretion. Our findings in humans are therefore consistent with the notion that leptin acts as a permissive factor, or so-called "metabolic gate" (37), for the development of puberty, permitting its progress only when other leptin-independent signals affecting the timing of the onset of puberty are present.

Prior to treatment, the two patients tested (B and C) showed selective $\mathrm{CD} 4^{+} \mathrm{T}$ cell lymphopenia and severely impaired lymphocyte function, comparable with that observed in anergic-hyporesponsive $\mathrm{T}$ cells. This stage of hyporesponsivness could, at least in part, be explained by the moderate to severe $\mathrm{CD} 4^{+} \mathrm{T}$ cell lymphopenia and the secretion of Th2/regulatory cytokines such as IL-4, IL-10, and TGF- $\beta$, observed before treatment in the absence of any consistent IFN- $\gamma$ production. After recombinant leptin replacement, both the immunophenotype and the $\mathrm{T}$ cell responsiveness were significantly improved and in some experiments reached the levels observed in normal age-matched controls. The reduced responsiveness to $\mathrm{T}$ cell receptor-specific stimuli OKT3 and PPD observed after 6 months of r-metHuLeptin treatment in patient $\mathrm{C}$ could be related to the production of anti-r-metHuLeptin neutralizing Ab's. These results suggest that leptin is a key molecule in both $\mathrm{CD}^{+}$ $\mathrm{T}$ cell development and function in humans, as testified by the increased proportion of $\mathrm{CD} 4^{+}$naive $\mathrm{T}$ cells and the restored IFN- $\gamma$ secretion, respectively.

Ab's to r-metHuLeptin developed in all children after approximately 6 weeks and markedly altered the pharmacokinetics of the injected peptide, thus hampering interpretation of serum leptin levels. Because full-length leptin represents a novel antigen to these children, the development of an $\mathrm{Ab}$ response was not unexpected. The fluctuating nature of the anti-r-metHuLeptin Ab's may reflect the complicating factor that leptin deficiency is itself an immunodeficient state and that leptin administration leads to a switch from the secretion of predominantly Th2 to Th1 cytokines, which may directly influence $\mathrm{Ab}$ production. Ab's that were capable of neutralizing leptin activity in a bioassay appeared transiently in child $\mathrm{B}$. The appearance of this activity coincided with a relapse of hyperphagia and weight gain in child B between 24 and 28 months, and its disappearance coincided with the return of a clinical response. Similarly neutralizing Ab's were detected in child C after 6 months of r-metHuLeptin therapy and were associated with hyperphagia and weight gain. Whether or not these Ab's will eventually lead to a complete blockade of therapeutic efficacy is currently uncertain.

A major question concerning leptin relates to whether it is principally involved in the "switch" from the fed to the starved state (38), with maximal sensitivities to changes in its concentration occurring at very low plasma levels, or whether plasma leptin concentrations varying across the range of concentrations seen in normal humans actually continue to exert a dose-related effect in the control of fat mass. While our study should theoretically have been able to provide unprecedented information regarding the relationship between plasma leptin concentration and its biological effects, the rapid development of circulating Ab's to leptin in the children made meaningful interpretation of serum leptin concentrations difficult.

In a recent study of leptin-sufficient subjects, administration of twice-daily recombinant human leptin prevented the fall in energy expenditure and thyroid hormones seen after $10 \%$ weight loss (30). This study provides strong support for the notion that the metabolic and neuroendocrine changes associated with weight loss in normal humans are the result of a fall in serum leptin concentrations. The ability of leptin replacement (to physiological levels) to prevent these adaptive changes and thereby prevent rebound weight gain, are consistent with our observations in congenital leptin deficiency. The weight-reduced state may thus be considered a state of relative leptin deficiency.

The therapeutic response to r-metHuLeptin administration in these three children confirms the importance of leptin in the regulation of human body weight, fat mass, and appetite. The sustained beneficial effects seen in these subjects (continued for over 4 years in one subject) have rarely been reported with other pharmacotherapies for obesity.

Leptin administration permits the full progression of appropriately timed puberty, but does not appear to cause precocious activation of the pubertal process in younger children. Leptin therapy results in gradual but sustained improvements in hyperinsulinemia and lipid profile. Of particular note is the relatively acute effects on circulating thyroid hormone concentrations, providing compelling evidence in humans that leptin is a regulator of the hypothalamic-pituitary-thyroidal axis. Finally, we have described, we believe for the first time, the immunodeficient state associated with human leptin deficiency and its reversal by leptin therapy. It is plausible that leptin's effects on human neuroendocrine function and $\mathrm{T}$ cell-mediated immunity may extend beyond the paradigm of congenital leptin deficiency and that leptin therapy may be more generally applicable in other disorders characterized by hypoleptinemia. This has been demonstrated recently by the sustained metabolic improvements seen with leptin therapy in human lipodystrophic disorders (39). Given the immunoregulatory properties of leptin on $\mathrm{CD} 4^{+} \mathrm{T}$ cells, increasing clinical applications of this hormone can be hypothesized. Indeed, in immunodeficiencies associated with anorexia nervosa and HIV-1 infection, leptin levels are dramatically reduced (40), as are $\mathrm{CD} 4^{+} \mathrm{T}$ cell number and function. Leptin administration could conceivably be a useful therapeutic tool to help the immunoreconstitution process in such patients, considering its effects on the thymic output of $T$ cells and cell-mediated immune response (40-42). 


\section{Acknowledgments}

We thank C. Cheetham and A. Earley for help with clinical studies, $\mathrm{S}$. Jones for body composition analysis, and A. Wright and A. Coward for doubly labeled water analysis. This work is supported by grants from The Wellcome Trust (to I.S. Farooqi), Medical Research Council UK (to S. O'Rahilly), and a grant from AMGEN Inc. for clinical studies.

1. Zhang, Y., et al. 1994. Positional cloning of the mouse obese gene and its human homologue. Nature. 372:425-432.

2. Swerdloff, R.S., Batt, R.A., and Bray, G.A. 1976. Reproductive hormonal function in the genetically obese $(o b / o b)$ mouse. Endocrinology. 98:1359-1364.

3. Dubuc, P.U. 1977. Basal corticosterone levels of young ob/ob mice. Horm. Metab. Res. 9:95-97.

4. Trayhurn, P., Thurlby, P.L., and James, W.P.T. 1977. Thermogenic defect in pre-obese $o b / o b$ mice. Nature. 266:60-62.

5. Ohtake, M., Bray, G.A., and Azukizawa, M. 1977. Studies on hypothermia and thyroid function in the obese $(o b / o b)$ mouse. Am. J. Physiol. 233:110-115.

6. Bray, G.A., and York, D.A. 1971. Genetically transmitted obesity in rodents. Physiol. Rev. 51:598-646.

7. Lord, G.M., et al.1998. Leptin modulates the T-cell immune response and reverses starvation-induced immunosuppression. Nature. 394:897-901.

8. Campfield, L.A., Smith, F.J., Guisez, Y., Devos, R., and Burn, P. 1995. Recombinant mouse OB protein: evidence for a peripheral signal linking adiposity and central neural networks. Science. 269:546-549.

9. Halaas, J.L., et al. 1995. Weight-reducing effects of the plasma protein encoded by the obese gene. Science. 269:543-546.

10. Pelleymounter, M.A., et al. 1995. Effects of the obese gene product on body weight regulation in $o b / o b$ mice. Science. 269:540-543.

11. Chehab, F.F., Lim, M.E., and Lu, R. 1996. Correction of the sterility defect in homozygous obese female mice by treatment with the human recombinant leptin. Nat. Genet. 12:318-320.

12. Barash, I.A., et al. 1996. Leptin is a metabolic signal to the reproductive system. Endocrinology. 137:3144-3147.

13. Montague, C.T., et al. 1997. Congenital leptin deficiency is associated with severe early-onset obesity in humans. Nature. 387:903-908.

14. Farooqi, I.S., et al. 1999. Effects of recombinant leptin therapy in a child with congenital leptin deficiency. N. Engl. J. Med. 341:879-884.

15. Jebb, S.A. 1997. Measurement of soft tissue composition by dual energy $\mathrm{x}$-ray absorptiometry. Br. J. Nutr. 77:151-163.

16. Panel on Dietary Reference Values of the Committee on Medical Aspects of Food Policy. 1991. Dietary reference values for food energy and nutrients for the United Kingdom. Report of the Panel on Dietary Reference Values of the Committee on Medical Aspects of Food Policy. Her Majesty's Stationery Office. London, United Kingdom. 1-210.

17. Murgatroyd, P.R., Shetty, P.S., and Prentice, A.M. 1993. Techniques for the measurement of human energy expenditure: a practical guide. Int. J. Obes. Relat. Metab. Disord. 17:549-568.

18. Fomon, S.J., Haschke, F., Ziegler, E.E., and Nelson, S.E. 1982. Body composition of reference children from birth to age 10 years. Am.J. Clin. Nutr. 35:1169-1175.

19. Hamill, P.V., et al. 1979. Physical growth: National Center for Health Statistics percentiles. Am. J. Clin. Nutr. 32:607-629.

20. Matarese, G., et al. 2001. Requirement for leptin in the induction and progression of autoimmune encephalomyelitis. J. Immunol. 166:5909-5916.

21. Heymsfield, S.B., et al. 1999. Recombinant leptin for weight loss in obese and lean adults: a randomized, controlled, dose-escalation trial. JAMA. 282:1568-1575.
22. Baskin, D.G., et al. 1998. Increased expression of mRNA for the long form of the leptin receptor in the hypothalamus is associated with leptin hypersensitivity and fasting. Diabetes. 47:538-543.

23. Franssila-Kallunki, A., et al. 1992. Weight loss by very-low-calorie diets: effects on substrate oxidation, energy expenditure, and insulin sensitivity in obese subjects. Am. J. Clin. Nutr. 56(Suppl.):247S-248S

24. Doucet, E., et al. 2000. Changes in energy expenditure and substrate oxidation resulting from weight loss in obese men and women: is there an important contribution of leptin? J. Clin. Endocrinol. Metab. 85:1550-1556

25. Weinsier, R.L., et al. 2000. Energy expenditure and free-living physical activity in black and white women: comparison before and after weight loss. Am. J. Clin. Nutr. 71:1138-1146.

26. Rouru, J., Cusin, I., Zakrzewska, K.E., Jeanrenaud, B., and Rohner-Jeanrenaud, F. 1999. Effects of intravenously infused leptin on insulin sensitivity and on the expression of uncoupling proteins in brown adipose tissue. Endocrinology. 140:3688-3692.

27. Havel, P.J. 2000. Role of adipose tissue in body-weight regulation: mechanisms regulating leptin production and energy balance. Proc. Nutr. Soc 59:69-71.

28. Harris, M., et al. 2001. Transcriptional regulation of the thyrotropinreleasing hormone gene by leptin and melanocortin signaling. J. Clin Invest. 107:111-120.

29. Nillni, E.A., et al. 2000. Leptin regulates prothyrotropin-releasing hormone biosynthesis. Evidence for direct and indirect pathways. J. Biol. Chem. 275:36124-36133.

30. Rosenbaum, M., Murphy, E.M., Heymsfield, S.B., Matthews, D.E., and Leibel, R.L. 2002. Low dose leptin administration reverses effects of sustained weight-reduction on energy expenditure and circulating concentrations of thyroid hormones. J. Clin. Endocrinol. Metab. 87:2391-2394.

31. Mantzoros, C.S., et al. 2001. Synchronicity of frequently sampled thyrotropin (TSH) and leptin concentrations in healthy adults and leptindeficient subjects: evidence for possible partial TSH regulation by leptin in humans. J. Clin. Endocrinol. Metab. 86:3284-3291.

32. Dubuc, P.U. 1989. Thyroid hormone responses to feeding in $o b / o b$ mice. Horm. Metab. Res. 21:546-549.

33. Strobel, A., Issad, T., Camoin, L., Ozata, M., and Strosberg, A.D. 1998. A leptin missense mutation associated with hypogonadism and morbid obesity. Nat. Genet. 18:213-215.

34. Ozata, M., Ozdemir, I.C., and Licinio, J. 1999. Human leptin deficiency caused by a missense mutation: multiple endocrine defects, decreased sympathetic tone, and immune system dysfunction indicate new targets for leptin action, greater central than peripheral resistance to the effects of leptin, and spontaneous correction of leptin-mediated defects. J. Clin. Endocrinol. Metab. 84:3686-3695.

35. Clement, K., et al. 1998. A mutation in the human leptin receptor gene causes obesity and pituitary dysfunction. Nature. 392:398-401.

36. Mantzoros, C.S., Flier, J.S., and Rogol, A.D. 1997. A longitudinal assessment of hormonal and physical alterations during normal puberty in boys. Rising leptin levels may signal the onset of puberty. J. Clin. Endocrinol. Metab. 82:1066-1070.

37. Cheung, C.C., et al. 1997. Leptin is a metabolic gate for the onset of puberty in the female rat. Endocrinology. 138:855-858.

38. Ahima, R.S., et al. 1996. Role of leptin in the neuroendocrine response to fasting. Nature. 382:250-252.

39. Oral, E.A., et al. 2002. Leptin-replacement therapy for lipodystrophy. N. Engl. J. Med. 346:570-578.

40. Matarese, G., et al. 2002. Balancing susceptibility to infection and autoimmunity: a role for leptin? Trends Immunol. 23:182-186.

41. Howard, J.K., et al. 1999. Leptin protects mice from starvation-induced lymphoid atrophy and increases thymic cellularity in $o b / o b$ mice. J. Clin. Invest. 104:1051-1059.

42. Martin-Romero, C., Santos-Alvarez, J., Goberna, R., and Sanchez-Margalet, V. 2000. Human leptin enhances activation and proliferation of human circulating T lymphocytes. Cell Immunol. 199:15-24. 